\title{
The Role of Parenteral Lipids in Supporting Gluconeogenesis in Very Premature Infants
}

\author{
AGNETA L. SUNEHAG
}

Children's Nutrition Research Center, USDA/ARS, Baylor College of Medicine, Houston, Texas 77030, U.S.A.

\begin{abstract}
We have previously demonstrated that very premature infants receiving glucose at $17 \mu \mathrm{mol} / \mathrm{kg}$ min plus appropriate supply of parenteral lipids (Intralipid $\left.{ }^{\circledR}\right)$ and amino acids (TrophAmine ${ }^{\circledR}$ ) maintained normoglycemia by glucose produced primarily via gluconeogenesis. The present study addressed the individual roles of parenteral lipids and amino acids in supporting gluconeogenesis. Fourteen premature infants $(993 \pm 36 \mathrm{~g} 27 \pm 1 \mathrm{wk})$ (mean $\pm \mathrm{SE}$ ) were studied for $8 \mathrm{~h}$ on d $5 \pm 1$ of life. All infants were receiving standard TPN prior to the study. At start of study, the glucose infusion rate was decreased to $\sim 17 \mu \mathrm{mol} / \mathrm{kg}$ min and either Intralipid ${ }^{\circledR}(\mathrm{g}+\mathrm{AA} ; n=8)$ or TrophAmine ${ }^{\circledR}(\mathrm{g}+\mathrm{IL} ; n$ $=6$ ) was discontinued. Data from 14 previously studied infants receiving glucose $(\sim 17 \mu \mathrm{mol} / \mathrm{kg} \min )+$ TrophAmine ${ }^{\circledR}+$ Intralipid $\AA(\mathrm{g}+\mathrm{AA}+\mathrm{IL})$ are included for comparison. Gluconeogenesis was measured by $\left[\mathrm{U}^{13} \mathrm{C}\right]$ glucose, $(\mathrm{g}+\mathrm{AA})$ and $(8$
\end{abstract}

ABSTRACT

infants of the $\mathrm{g}+\mathrm{AA}+\mathrm{IL}$ group) or $\left[2-{ }^{13} \mathrm{C}\right]$ glycerol, $(\mathrm{g}+\mathrm{IL})$ and ( 6 infants of the $g+$ AA + IL group). Infants studied by the

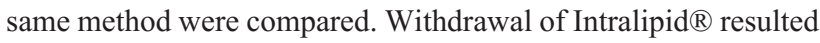
in decreased gluconeogenesis, $6.3 \pm 0.9(\mathrm{~g}+\mathrm{AA}) v s .8 .4 \pm 0.7$ $\mu \mathrm{mol} / \mathrm{kg} \min (\mathrm{g}+\mathrm{AA}+\mathrm{IL})(p=0.03)$. Withdrawal of TrophAmine ${ }^{\circledR}$ affected neither total gluconeogenesis, $7.5 \pm 0.8$ vs. $7.9 \pm 0.9 \mu \mathrm{mol} / \mathrm{kg}$ min nor gluconeogenesis from glycerol, $4.4 \pm 0.6 v s .4 .9 \pm 0.7 \mu \mathrm{mol} / \mathrm{kg} \min (\mathrm{g}+\mathrm{IL}$ and $\mathrm{g}+\mathrm{AA}+\mathrm{IL}$ groups, respectively). In conclusion, in parenterally fed very premature infants, lipids play a primary role in supporting gluconeogenesis. (Pediatr Res 54: 480-486, 2003)

\section{Abbreviations}

MIDA, mass isotopomer distribution analysis TPN, total parenteral nutrition
The majority of infants with birth weights of $1500 \mathrm{~g}$ and less survive the neonatal period in the United States today (1). This has led to increased need for long-term nutritional support to sustain normal growth and development without complications. Thus, defining the role and effects of individual macronutrients is fundamental in improving our current treatment practices.

In humans, the brain consumes about 20 times more glucose per $100 \mathrm{~g}$ tissue than, for example, muscle and fat $(2,3)$. Because infants born prematurely have a large brain in relation to their body weight (about six times that of an adult), their glucose demands on a body weight basis are high $(3,4)$. To prevent hypoglycemia and provide a sufficient energy intake, premature infants are dependent on TPN during their first week(s) of life. However, many very premature infants, par-

Received May 27, 2002; accepted April 4, 2003.

Correspondence: Agneta L. Sunehag, Children's Nutrition Research Center, 1100 Bates Street, Houston, TX 77030, U.S.A; e-mail: asunehag@bcm.tmc.edu

Supported by National Institutes of Health grant RO1 HD 37857, USDA Cooperative Agreement \#58-6250-6-001, and RO1 DK 55478.

This work is a publication of the USDA/ARS Children's Nutrition Research Center, Department of Pediatrics, Baylor College of Medicine, Houston, TX. The contents of this publication do not necessarily reflect the views of policies of the U.S. Department of Agriculture, nor does mention of trade names, commercial products, or organizations imply endorsement from the U.S. Government.

DOI: 10.1203/01.PDR.0000081298.06751.76 ticularly the smallest and most sick infants, have a reduced tolerance for parenteral glucose resulting in a high incidence of hyperglycemia when glucose is infused at rates exceeding basal glucose turnover rates, as is the standard practice (5-7).

We have previously demonstrated that very premature infants receiving glucose at half their normal basal glucose turnover rates in conjunction with appropriate amounts of lipid (Intralipid, Fresenius KABI, Uppsala, Sweden) and amino acid substrates (TrophAmine, McGaw, Irvine, CA, U.S.A.) maintain normoglycemia by production of glucose primarily via gluconeogenesis (8). Under these conditions, glycerol was the primary substrate for gluconeogenesis (8). However, it was not possible to determine the relative impact of the lipid and amino acid components of TPN. Thus, the purpose of the present study was to test the hypothesis that withdrawal of Intralipid has greater impact on gluconeogenesis than withdrawal of TrophAmine, which would suggest that parenteral lipids are more important than the amino acids provided by TrophAmine in supporting gluconeogenesis.

\section{METHODS}

Subjects. All protocols were reviewed and approved by the Institutional Review Board for Human Research at Baylor College of Medicine in Houston, TX. The subjects were re- 
cruited from the neonatal intensive care unit at Texas Children's Hospital. Parents of eligible infants were approached after approval from the attending physician. The details of the study were explained to the parent(s). If necessary, they were given up to 48 additional hours to study the consent form before agreeing to sign it. The infants were enrolled only after written consent was obtained from at least one parent.

Eligible infants were those with birth weights $\geq 750 \mathrm{~g}$ and appropriately sized for a gestational age of $\leq 29$ wk $(9,10)$. Infants with asphyxia at birth (Apgar scores $<5$ at $5 \mathrm{~min}$ ), congenital malformations, discernible disease, or signs of sepsis were excluded. Further excluded were infants of diabetic mothers, infants requiring $>30 \%$ oxygen, and infants treated with insulin before or at time of the study. Only infants with both umbilical vein and artery catheters in place were included.

Fourteen infants were studied, five girls and nine boys, of which five were Caucasian, four African American, four Hispanic, and one Asian. The majority of the mothers (12/14) had received antenatal steroids (betamethasone, one to five doses, $12 \mathrm{mg}$ each). In the previous study (8), antenatal steroids had no effect on glucose production and gluconeogenesis. The infants were born after $27 \pm 1$ wk of gestation (mean \pm SE) (Table 1). They were appropriate for gestational age $(9,10)$ with birth weights averaging $993 \pm 36 \mathrm{~g}$ (Table 1). The infants had Apgar scores at 5 min between 7 and 9 .

According to the nursery's clinical practice guidelines, all of the infants had received two to four doses of surfactant (Survanta, Abbot Laboratories, Columbus, OH, U.S.A.) before the study. Further, consistent with the routines in the nursery, the infants were managed according to a minimal stimulation program, which included intubation, ventilation, and sedation with phenobarbital $(5 \mathrm{mg} / \mathrm{kg} / \mathrm{d})$. All infants were clinically stable with normal heart rate and blood pressure, had normal temperature under radiant warmers, oxygen saturation of 95 $98 \%$, normal acid base status ( $\mathrm{pH} 7.3 \pm 0.02)$, and normal $\mathrm{PCO}_{2}$ ( $40 \pm 2$ torr). At the time of the study, i.e. on d $5 \pm 1$ of life, all infants were on minimal ventilatory settings with mean positive inspiratory pressure of $19 \pm 1 \mathrm{~cm} \mathrm{H}_{2} \mathrm{O}$ and positive end-expiratory pressure of $5 \pm 1 \mathrm{~cm} \mathrm{H}_{2} \mathrm{O}$, and $24 \pm 1 \%$ oxygen supply. None of the infants was treated with caffeine, dopamine, or insulin. Five infants were on prophylactic treatment with antibiotics because of premature rupture of the membranes but none had positive blood cultures or any clinical signs of septicemia.

Table 1. Subject characteristics

\begin{tabular}{|c|c|c|c|c|}
\hline Subjects & No. & $\begin{array}{c}\text { Gestational Age } \\
\text { (wk) }\end{array}$ & $\begin{array}{c}\text { Birth Weight } \\
\text { (g) }\end{array}$ & $\begin{array}{l}\text { Postnatal Age } \\
\text { (d) }\end{array}$ \\
\hline $\mathrm{g}+\mathrm{AA}$ & 8 & $27 \pm 1$ & $973 \pm 49$ & $5 \pm 1$ \\
\hline $\mathrm{g}+\mathrm{IL}$ & 6 & $28 \pm 1$ & $1022 \pm 57$ & $5 \pm 1$ \\
\hline$(\mathrm{g}+\mathrm{AA}+\mathrm{IL})_{[\mathrm{U} 13 \mathrm{C}] \text { glucose }}$ & 8 & $27 \pm 1$ & $961 \pm 38$ & $5 \pm 1$ \\
\hline$(\mathrm{g}+\mathrm{AA}+\mathrm{IL})_{[2-13 \mathrm{C}] \text { glycerol }}$ & 16 & $28 \pm 1$ & $1095 \pm 39$ & $5 \pm 1$ \\
\hline
\end{tabular}

The designed glucose infusion rate in all infants was $\sim 17 \mu \mathrm{mol} / \mathrm{kg} / \mathrm{min}$ (3 $\mathrm{mg} / \mathrm{kg} / \mathrm{min})$. The $\mathrm{g}+\mathrm{AA}$ group also received TrophAmine $(2.3 \pm 0.1$ $\mathrm{mg} / \mathrm{kg} / \mathrm{d})$; the $\mathrm{g}+\mathrm{IL}$ group received Intralipid $(1.7 \pm 0.4 \mathrm{mg} / \mathrm{kg} / \mathrm{d})$, and the previously studied $(\mathrm{g}+\mathrm{AA}+\mathrm{IL})_{[\mathrm{U}-13 \mathrm{C}] \text { glucose }}$ and $(\mathrm{g}+\mathrm{AA}+\mathrm{IL})_{[2-13 \mathrm{C}] \text { glycerol }}$ groups received Intralipid $(1.6 \pm 0.1 \mathrm{mg} / \mathrm{kg} / \mathrm{d})$ plus TrophAmine $(2.2 \pm 0.1$ $\mathrm{mg} / \mathrm{kg} / \mathrm{d}$ ) (no difference between the two groups) (8).
Tracers. $\left[\mathrm{U}^{13} \mathrm{C}\right]$ glucose $\left(98+\right.$ atom $\left.\%{ }^{13} \mathrm{C} ; 93.8 \%{ }^{13} \mathrm{C}{ }_{6}\right)$ and $\left[2-{ }^{13} \mathrm{C}\right]$ glycerol $\left(99\right.$ atom $\%{ }^{13} \mathrm{C}$ ) were purchased from Cambridge Isotope Laboratories (Andover, MA, U.S.A.). The tracers were tested for sterility and pyrogenicity, dissolved in isotonic saline, and prepared for i.v. infusion by the research pharmacy at Texas Children's Hospital.

Administration of tracers and parenteral nutrition solutions. Both solutions were administered via umbilical venous catheters. All isotopes were administered by syringe infusion pumps (Medinfusion 2010, Medex, Inc., Duluth, GA, U.S.A.).

Parenteral nutrition. At start of the study, the infants were receiving TPN (glucose, Intralipid, and TrophAmine) according to the routines in the nursery (8). The prestudy TPN did not differ between the two study groups described below or when compared with that of the previous study (8). None of the infants had received any enteral feeding. To avoid any acute hypoglycemia and, thus, diminish acute counter-regulatory hormone responses, the glucose infusion rate was reduced step-wise from $57 \mu \mathrm{mol} / \mathrm{kg} / \mathrm{min}(10.3 \mathrm{mg} / \mathrm{kg} / \mathrm{min})$ at start of the study (zero time) to $\sim 33 \mu \mathrm{mol} / \mathrm{kg} / \mathrm{min}(6 \mathrm{mg} / \mathrm{kg} / \mathrm{min})$ over the first study hour and then to $\sim 17 \mu \mathrm{mol} / \mathrm{kg} \min (3 \mathrm{mg} / \mathrm{kg} /$ min) (approximate half basal glucose turnover rate) for the remaining 7 study hours in all infants (Table 2) (see details below under "Infusions of tracers and glucose"). In one group of infants denoted "g $+\mathrm{AA}$ " $(n=8)$, TrophAmine was continued at $2.3 \pm 0.1 \mathrm{mg} / \mathrm{kg} / \mathrm{min}$ over the entire study period $(8 \mathrm{~h})$ (i.e. only Intralipid was discontinued at zero time) (Table $2)$. In a second group, denoted "g $+\mathrm{IL}$ " $(n=6)$, Intralipid was continued at $1.7 \pm 0.4 \mathrm{mg} / \mathrm{kg} / \mathrm{min}$ throughout the study $(8 \mathrm{~h})$ (i.e. only TrophAmine was discontinued at start of the study) (Table 2). Fourteen previously reported infants with identical characteristics, receiving glucose at the reduced rate plus both TrophAmine and Intralipid at the rates mentioned above were included for comparison (8). These infants are denoted " $\mathrm{g}+$ AA + IL." Thus, the glucose supply was similar in the three groups. In addition, the rates of amino acid and lipid infusion (when infused), were maintained constant, whether each substrate was given alone ( $\mathrm{g}+\mathrm{AA}$ and $\mathrm{g}+\mathrm{IL}$, respectively) or together $(\mathrm{g}+\mathrm{AA}+\mathrm{IL})$. As a result, there was a very small difference in the energy intake (a total of $3.0 \mathrm{kcal} / \mathrm{kg}$ over the 8-h study period) between the $\mathrm{g}+\mathrm{AA}$ and the $\mathrm{g}+\mathrm{IL}$ groups (Table 2).

Measurements of parameters of glucose metabolism. In all infants, total plasma glucose appearance rates (and subsequently glucose production rates) were measured by $\left[\mathrm{U}-{ }^{13} \mathrm{C}\right]$ glucose. Gluconeogenesis was estimated using MIDA during infusion of either $\left[\mathrm{U}-{ }^{13} \mathrm{C}\right]$ glucose $(11)$ or $\left[2-{ }^{13} \mathrm{C}\right]$ glycerol $(12,13)$ as described in detail previously $(8)$. These methods provided identical results in premature infants studied under similar conditions (8). In addition, we have demonstrated that $\left[\mathrm{U}_{-}{ }^{13} \mathrm{C}\right]$ glucose MIDA provided an estimate of total gluconeogenesis identical to that obtained using the deuterium oxide method with measurements of deuterium incorporation in glucose carbon 5 in healthy young adults studied after a $66-\mathrm{h}$ fast (14). The large sample sizes required with the deuterium oxide glucose carbon 5 method (15) preclude any direct comparison of this method with the other methods in preterm infants. As we have previously demonstrated (8), the deuterium 
Table 2. Substrate and energy provided by the parenteral nutrition over the 8-h study period

\begin{tabular}{|c|c|c|c|c|c|c|}
\hline Substrate & \multicolumn{2}{|c|}{ Infusion rate $(\mathrm{mg} / \mathrm{kg} \cdot \mathrm{min})$} & \multicolumn{2}{|c|}{ Infused amount $(\mathrm{g} / \mathrm{kg} / 8 \mathrm{~h})$} & \multicolumn{2}{|c|}{ Energy (kcal/kg/8 h) } \\
\hline Glucose & $3.6 \pm 0.2$ & $3.0 \pm 0.0$ & $1.9 \pm 0.1^{*}$ & $1.4 \pm 0.0^{*}$ & $6.4 \pm 0.3$ & $5.5 \pm 0.0$ \\
\hline Protein & $2.3 \pm 0.1$ & 0 & $1.1 \pm 0.0$ & 0 & $4.1 \pm 0.1$ & 0 \\
\hline Sum & - & - & - & - & $10.4 \pm 0.3$ & $13.4 \pm 0.8$ \\
\hline
\end{tabular}

Composition of TrophAmine (the content of each amino acid is expressed in $\mathrm{mg} / 100 \mathrm{~mL}$ of solution): arginine 1227; leucine 1200; proline 812; isoleucine 760; alanine 698; lysine 677; glutamic acid 620; aspartic acid 527; threonine 512; serine 495; phenylalanine 427; glycine 385; histidine 312; tryptophan 180; methionine 180; taurine 70; tyrosine 40; cysteine 0 .

* Includes the additional $16.7 \mu \mathrm{mol} / \mathrm{kg} / \mathrm{min}(3 \mathrm{mg} / \mathrm{kg} / \mathrm{min})$ administered during the first study hour.

oxide method with measurement of deuterium incorporation in glucose carbon 6 underestimates gluconeogenesis by an amount consistent with the fractional contribution from glycerol and would, therefore, have been inappropriate to use in the present study.

In the previously studied g + AA + IL group of 14 infants, eight infants were studied using $\left[\mathrm{U}_{-}{ }^{13} \mathrm{C}\right]$ glucose MIDA and six infants by $\left[2-{ }^{13} \mathrm{C}\right] \mathrm{glycerol}$ MIDA (8). In the present study, the infants included in the $\mathrm{g}+\mathrm{IL}$ group were studied using the $\left[2-{ }^{13} \mathrm{C}\right]$ glycerol tracer to permit partitioning of the gluconeogenic contribution from glycerol and nonglycerol sources $(8$, $12,13)$. Because the $\left[2-{ }^{13} \mathrm{C}\right]$ glycerol MIDA requires infusion of the glycerol tracer at high rates $(8,12,13,16)$, the infants receiving glucose plus TrophAmine were studied using the $\left[\mathrm{U}-{ }^{13} \mathrm{C}\right]$ glucose method to avoid a potential influence of any exogenous supply of glycerol. Although we have previously demonstrated that $\left[\mathrm{U}-{ }^{13} \mathrm{C}\right]$ glucose and $\left[2-{ }^{13} \mathrm{C}\right]$ glycerol MIDA provided identical estimates of gluconeogenesis (8), to completely exclude any potential effects of the stable isotope tracer chosen on comparisons of measures of gluconeogenesis among the groups, infants studied by the same tracer method were compared. Thus, the infants of the $\mathrm{g}+\mathrm{AA}$ group (studied by the $\left.\left[\mathrm{U}_{-}{ }^{13} \mathrm{C}\right] \mathrm{glucose} \mathrm{MIDA}\right)$ were compared with the eight infants of the $\mathrm{g}+\mathrm{AA}+\mathrm{IL}$ group studied by $\left[\mathrm{U}_{-}{ }^{13} \mathrm{C}\right]$ glucose MIDA, denoted $(\mathrm{g}+\mathrm{AA}+\mathrm{IL})_{[\mathrm{U}-13 \mathrm{C}] \mathrm{glucose}}$. The only difference between those two groups is the infusion of Intralipid, i.e. this comparison reflects the effects of withdrawal of Intralipid. Similarly, the infants of the $\mathrm{g}+\mathrm{IL}$ group (studied using $\left[2-{ }^{13} \mathrm{C}\right]$ glycerol MIDA), were compared with the infants studied previously using the same method i.e. $\left[2-{ }^{13} \mathrm{C}\right]$ glycerol MIDA $(n=6)$, denoted $(\mathrm{g}+\mathrm{AA}+\mathrm{IL})_{[2-13 \mathrm{C}] \mathrm{glyc} \text { cerol. }}$. The only difference between those two groups of infants is the infusion of TrophAmine, i.e. this comparison reflects the effects of withdrawal of TrophAmine.

Infusions of tracers and glucose. In the infants studied using $\left[\mathrm{U}_{-}{ }^{13} \mathrm{C}\right]$ glucose MIDA, i.e. the $\mathrm{g}+\mathrm{AA}$ and $(\mathrm{g}+\mathrm{AA}+$ IL) $[\mathrm{U}-13 \mathrm{C}] \mathrm{glucose}$ groups, an infusion of $\left[\mathrm{U}-{ }^{13} \mathrm{C}\right]$ glucose, metabolically equivalent to natural glucose, was begun at zero time and continued throughout the study period at $16.7 \pm 0.2$ $\mu \mathrm{mol} / \mathrm{kg} / \mathrm{min}(3.0+0.0 \mathrm{mg} / \mathrm{kg} / \mathrm{min})$. During the first hour of the infusion period, the infants received an additional 16.7 $\mu \mathrm{mol} / \mathrm{kg} / \mathrm{min}(3 \mathrm{mg} / \mathrm{kg} / \mathrm{min})$ of natural glucose. Thereafter, $\left[\mathrm{U}-{ }^{13} \mathrm{C}\right]$ glucose represented the entire source of exogenous glucose except in three infants in the g + AA group, who received some additional unlabeled glucose to maintain normoglycemia. Thus, the total infusion rates of glucose were 19.7 $\pm 1.0 \mu \mathrm{mol} / \mathrm{kg} / \mathrm{min}(3.6 \pm 0.2 \mathrm{mg} / \mathrm{kg} / \mathrm{min})$ in the $\mathrm{g}+\mathrm{AA}$ group compared with $16.8 \pm 0.2 \mu \mathrm{mol} / \mathrm{kg} / \mathrm{min}(3.0 \pm 0.1$ $\mathrm{mg} / \mathrm{kg} / \mathrm{min})(\mathrm{NS})$ in the previously studied $(\mathrm{g}+\mathrm{AA}+\mathrm{IL})_{[\mathrm{U}-}$ 13C]glucose group $(n=8)$.

In the infants studied using $\left[2-{ }^{13} \mathrm{C}\right]$ glycerol MIDA, i.e. the $\mathrm{g}$ $+\mathrm{IL}$ and $(\mathrm{g}+\mathrm{AA}+\mathrm{IL})_{[2-13 \mathrm{C}] \text { glycerol }}$ groups, the glucose supply was represented by natural glucose. The total amount of glucose given to the $\mathrm{g}+\mathrm{IL}$ group $(16.7 \pm 0.1 \mu \mathrm{mol} / \mathrm{kg} / \mathrm{min}$, $3.0 \pm 0.0 \mathrm{mg} / \mathrm{kg} / \mathrm{min}$ ) did not differ significantly from that administered to the $(\mathrm{g}+\mathrm{AA}+\mathrm{IL})_{[2-13 \mathrm{C}] \mathrm{glycerol}}$ group $[17.8 \pm$ $0.7 \mu \mathrm{mol} / \mathrm{kg} / \mathrm{min}(3.2 \pm 0.1 \mathrm{mg} / \mathrm{kg} / \mathrm{min})]$ or from those of the $\mathrm{g}+\mathrm{AA}$ and $(\mathrm{g}+\mathrm{AA}+\mathrm{IL})_{[\mathrm{U}-13 \mathrm{C}] \mathrm{glucose}}$ groups. From zero hour to the end of the study, $\left[2-{ }^{13} \mathrm{C}\right]$ glycerol was infused at a constant rate of $3.9 \pm 0.1 \mu \mathrm{mol} / \mathrm{kg} / \mathrm{min}(0.4 \pm 0.1 \mathrm{mg} / \mathrm{kg} / \mathrm{min})$. In addition, [U- ${ }^{13} \mathrm{C}$ ]glucose was infused at $0.46 \pm 0.02 \mu \mathrm{mol} /$ $\mathrm{kg} / \mathrm{min}(0.08 \pm 0.01 \mathrm{mg} / \mathrm{kg} / \mathrm{min})$. We have previously demonstrated that at this low infusion rate, singly and doubly labeled glucose molecules derived from the $\left[\mathrm{U}^{13} \mathrm{C}\right]$ glucose tracer are negligible (8) and, therefore, do not interfere with assessment of glycerol ${ }^{13} \mathrm{C}$ appearance in blood glucose.

Blood sampling. All blood samples were drawn from umbilical artery catheters already in place for clinical care purposes. The umbilical artery catheters were kept patent with isotonic saline both before and during the study period $(0.2$ $\mathrm{mL} / \mathrm{h}$ with heparin 1 unit $/ \mathrm{mL}$ ). Samples for analysis of blood glucose concentration, mass isotopomer distribution of plasma glucose and lactate and ${ }^{13} \mathrm{C}$ enrichment in plasma glycerol were obtained before the start of the tracer infusions (baseline), and then at 4, 6, and $8 \mathrm{~h}$ in both the $\mathrm{g}+\mathrm{AA}$ and $\mathrm{g}+\mathrm{IL}$ groups and the previously studied $(\mathrm{g}+\mathrm{AA}+\mathrm{IL})_{[\mathrm{U}-13 \mathrm{C}] \text { glucose }}$ and (g $+\mathrm{AA}+\mathrm{IL})_{[2-13 \mathrm{C}] \text { glycerol }}$ groups. Plasma insulin concentrations were measured in the baseline sample and at the end of the study in all infants. In addition, blood glucose concentrations were measured hourly at the bedside to ensure that normoglycemia (blood glucose $\geq 40 \mathrm{mg} / \mathrm{dL}$ or $\geq 2.2 \mathrm{mM}$ ) was maintained (17-19). All of the infants included in the $g+$ IL group and in the previously studied $(\mathrm{g}+\mathrm{AA}+\mathrm{IL})_{[\mathrm{U}-13 \mathrm{C}] \text { glucose }}$ and the $(\mathrm{g}+\mathrm{AA}+\mathrm{IL})_{[2-13 \mathrm{C}] \mathrm{glycerol}}$ groups maintained blood glucose above $2.2 \mathrm{mM}$ on the designed glucose infusion rate $[\sim 17 \mu \mathrm{mol} / \mathrm{kg} / \mathrm{min}(3 \mathrm{mg} / \mathrm{kg} / \mathrm{min})]$ during the study, whereas in three infants in the $\mathrm{g}+\mathrm{AA}$ group, the glucose infusion rate was increased by $5.2,7.9$, and $8.3 \mu \mathrm{mol} / \mathrm{kg} / \mathrm{min}(0.9,1.4$, and $1.5 \mathrm{mg} / \mathrm{kg} / \mathrm{min}$ ), respectively, because of blood glucose concentrations that transiently decreased to 36,36 , and $37 \mathrm{mg} / \mathrm{dL}$ $(2.0,2.0$, and $2.1 \mathrm{mM})$, respectively. In all three infants, the blood glucose concentration responded immediately to the 
increase in exogenous glucose and remained stable at 50,51, and $59 \mathrm{mg} / \mathrm{dL}(2.8,2.8$, and $3.3 \mathrm{mM})$, respectively, from study hour 2 to the end of the study.

The total blood volume withdrawn in each of these studies was $\leq 2.5 \mathrm{~mL}$. The small blood sample volume precluded analyses of concentrations of FFA, ketone bodies, and glucagon.

Analyses. Blood glucose concentrations were measured using a glucose analyzer (YSI 2300 Stat Plus, YSI Inc, Yellow Springs, OH, U.S.A.), and plasma insulin concentrations using a conventional RIA (Linco, St Charles, MO, U.S.A.) with a detection limit of $0.5 \mu \mathrm{U} / \mathrm{mL}$. The mass isotopomer distribution of glucose and lactate during infusion of $\left[\mathrm{U}_{-}{ }^{13} \mathrm{C}\right]$ glucose and of glucose during infusion of $\left[2-{ }^{13} \mathrm{C}\right]$ glycerol and enrichments of $\left[2-{ }^{13} \mathrm{C}\right]$ glycerol were measured by gas chromatography-mass spectrometry (GCMS) as described previously (8).

Calculations. Approximate steady states (defined by a coefficient of variation of $<10 \%$ ) for substrate concentrations and isotopic enrichments were achieved between study hours 6 an 8. Thus, all calculations are based on data obtained during this period (Table 3).

Total plasma glucose appearance rates were calculated from the ${ }^{13} \mathrm{C}_{6}$ enrichment of glucose using established isotope dilution equations $(20,21)$ :

Total plasma glucose appearance rate $=\left(\mathrm{E}_{1} / \mathrm{E}_{\mathrm{p}}\right) \times \mathrm{I}$,

where $E_{i}$ is the ${ }^{13} C_{6}$ enrichment of the infusate, $E_{p}$ is the ${ }^{13} C_{6}$ enrichment in plasma, and $\mathrm{I}$ is the infusion rate of $\left[\mathrm{U}_{-}{ }^{13} \mathrm{C}\right] \mathrm{glu}-$ cose $(\mu \mathrm{mol} / \mathrm{kg} / \mathrm{min})$.

Glucose production rates were calculated by subtracting the glucose infusion rate from total glucose appearance rate. The glucose infusion rate is the sum of all labeled and unlabeled glucose infused, i.e. $\left[\mathrm{U}^{13} \mathrm{C}\right]$ glucose plus natural glucose.

Fractional gluconeogenesis was calculated using $\left[\mathrm{U}-{ }^{13} \mathrm{C}\right]$ glucose $(8,11)$ or $\left[2-{ }^{13} \mathrm{C}\right]$ glycerol MIDA $(8,12,13)$. Gluconeogenic rate is the product of fractional gluconeogenesis and total plasma glucose appearance rate. The gluconeogenic contribution from glycerol was calculated using $\left[2-{ }^{13} \mathrm{C}\right]$ glycerol MIDA $(8,12,13)$. Glycogenolysis was calculated by subtracting rates of gluconeogenesis from the glucose production rates.
Total plasma glycerol appearance rates were measured using the isotope dilution equation described above for total plasma glucose appearance rates (22-24). Endogenous glycerol appearance rates (an indicator of lipolysis) were calculated by subtracting the exogenous contribution of glycerol from the $\left[2-{ }^{13} \mathrm{C}\right]$ glycerol tracer and the exogenous glycerol derived from Intralipid from the total plasma glycerol appearance rate.

Statistical analyses. All data are presented as mean \pm SE. Statistical significance is defined by a $p$ value $\leq 0.05$. Data obtained between study hours 6 and 8 in the g + AA group were compared with those obtained during the same time period in the $(\mathrm{g}+\mathrm{AA}+\mathrm{IL})_{[\mathrm{U}-13 \mathrm{C}] \mathrm{glucose}}$ group using two-tailed unpaired $t$ test. Similarly, the data obtained in the g + IL group between study hours 6 and 8 were compared with those of the $(\mathrm{g}+\mathrm{AA}+\mathrm{IL})_{[2-13 \mathrm{C}] \text { glycerol }}$ group.

\section{RESULTS}

Table 1 shows birth weight, gestational age, and postnatal age in the study groups. These parameters did not differ among the groups.

Insulin and glucose. Neither plasma insulin nor blood glucose concentrations at the start of the study differed significantly among the groups. During the first $2 \mathrm{~h}$ of the study period, the blood glucose concentrations fell in response to the decreased glucose infusion rate but subsequently remained stable in all groups: $\mathrm{g}+\mathrm{AA}(3.1 \pm 0.1 \mathrm{mM}), \mathrm{g}+\mathrm{IL}(4.5 \pm$ $0.1 \mathrm{mM})$, and the previously studied $(\mathrm{g}+\mathrm{AA}+\mathrm{IL})_{[\mathrm{U}-13 \mathrm{C}] \mathrm{glu}}{ }^{-}$ cose and $(\mathrm{g}+\mathrm{AA}+\mathrm{IL})_{[2-13 \mathrm{C}] \text { glycerol }}$ groups, $3.0 \pm 0.1$ and 2.8 $\pm 0.1 \mathrm{mM}$, respectively.

\section{Withdrawal of parenteral lipids (Intralipid)}

In the $\mathrm{g}+\mathrm{AA}$ group, three of eight infants required an increase in the glucose infusion rate above the designed 17 $\mu \mathrm{mol} / \mathrm{kg} / \mathrm{min}(\sim 3 \mathrm{mg} / \mathrm{kg} / \mathrm{min})$, resulting in total infusion rates of $22.2,25.3$, and $24.9 \mu \mathrm{mol} / \mathrm{kg} / \mathrm{min}(4.0,4.6$, and $4.5 \mathrm{mg} / \mathrm{kg} /$ $\mathrm{min})$, respectively, to maintain a blood glucose concentration above $2.2 \mathrm{mM}(40 \mathrm{mg} / \mathrm{dL})$. Because additional glucose was infused for maintenance of euglycemia, the blood glucose concentrations obtained between study hours 6 and 8 in the $g$ + AA group (3 $0.2 \pm 0.2 \mathrm{mM}$ ) were not different from those

Table 3. Mean isotopic enrichments of glucose, lactate, and glycerol isotopomers during infusion of $\left[\mathrm{U}-_{-}^{13} \mathrm{C}\right] \mathrm{glucose}$ and $\left[2{ }^{13} \mathrm{C}\right] \mathrm{glycerol}$

\begin{tabular}{|c|c|c|c|c|}
\hline Isotopomer & $\begin{array}{c}(\mathrm{g}+\mathrm{AA}+\mathrm{IL}) \\
{\left[\mathrm{U}-{ }^{13} \mathrm{C}\right] \mathrm{glucose}} \\
(6-8 \mathrm{~h})(\%)\end{array}$ & $\begin{array}{c}(\mathrm{g}+\mathrm{AA}+\mathrm{IL}) \\
{\left[2-{ }^{13} \mathrm{C}\right] \text { glycerol }} \\
(6-8 \mathrm{~h})(\%)\end{array}$ & $\begin{array}{c}\mathrm{g}+\mathrm{AA} \\
{\left[\mathrm{U}-{ }^{13} \mathrm{C}\right] \mathrm{glucose}} \\
(6-8 \mathrm{~h})(\%)\end{array}$ & $\begin{array}{c}\mathrm{g}+\mathrm{IL} \\
{\left[2-{ }^{13} \mathrm{C}\right] \text { glycerol }} \\
(6-8 \mathrm{~h})(\%)\end{array}$ \\
\hline${ }^{13} \mathrm{C}_{1}$ glucose & $4.40 \pm 0.39$ & $4.18 \pm 0.48$ & $2.93 \pm 0.21$ & $4.64 \pm 0.40$ \\
\hline${ }^{13} \mathrm{C}_{3}$ glucose & $3.65 \pm 0.32$ & - & $2.47 \pm 0.31$ & - \\
\hline${ }^{13} \mathrm{C}_{4}$ glucose & $0.80 \pm 0.07$ & - & $0.55 \pm 0.10$ & - \\
\hline${ }^{13} \mathrm{C}_{5}$ glucose & $0.47 \pm 0.08$ & - & $0.16 \pm 0.06$ & - \\
\hline${ }^{13} \mathrm{C}_{1}$ lactate & $5.48 \pm 0.22$ & - & $4.93 \pm 0.24$ & - \\
\hline${ }^{13} \mathrm{C}_{2}$ lactate & $5.23 \pm 0.20$ & - & $4.48 \pm 0.23$ & - \\
\hline${ }^{13} \mathrm{C}_{3}$ lactate & $31.51 \pm 1.55$ & - & $27.38 \pm 1.21$ & - \\
\hline
\end{tabular}

The $\mathrm{g}+\mathrm{AA}+\mathrm{IL}$ group includes infants studied previously using either $\left[\mathrm{U}_{-}{ }^{13} \mathrm{C}\right]$ glucose $(n=8)$ or $\left[2-{ }^{13} \mathrm{C}\right]$ glycerol MIDA $(n=6)$. These infants received glucose at $\sim 17 \mu \mathrm{mol} / \mathrm{kg} / \mathrm{min}(\sim 3 \mathrm{mg} / \mathrm{kg} / \mathrm{min})$ plus Intralipid plus TrophAmine (8). The $\mathrm{g}+\mathrm{AA}$ group $(n=8)$ received glucose at $\sim 17 \mu \mathrm{mol} / \mathrm{kg} / \mathrm{min}(\sim 3$ $\mathrm{mg} / \mathrm{kg} / \mathrm{min})$ plus TrophAmine and were studied by $\left[\mathrm{U}-{ }^{13} \mathrm{C}\right]$ glucose MIDA. The $\mathrm{g}+\mathrm{IL}$ group $(n=6)$ received glucose at $\sim 17 \mu \mathrm{mol} / \mathrm{kg} / \mathrm{min}(\sim 3 \mathrm{mg} / \mathrm{kg} / \mathrm{min})$ plus Intralipid and were studied by $\left[2-{ }^{13} \mathrm{C}\right]$ glycerol MIDA. 
of the previously studied (g + AA + IL) ${ }_{[\mathrm{U}-13 \mathrm{C}] \text { glucose }}$ group ( $n$ $=8)(3.0 \pm 0.1 \mathrm{mM})$. The plasma insulin concentrations at the end of the study period were $6.3 \pm 0.9(\mathrm{~g}+\mathrm{AA})$ versus $9.9 \pm$ $1.4 \mu \mathrm{U} / \mathrm{mL}(\mathrm{g}+\mathrm{IL}+\mathrm{AA})_{[\mathrm{U}-13 \mathrm{C}] \mathrm{glucose}}(p=0.08)$.

Withdrawal of Intralipid resulted in a decrease in rates of gluconeogenesis, $6.3 \pm 0.4(1.1 \pm 0.1 \mathrm{mg} / \mathrm{kg} / \mathrm{min})(\mathrm{g}+\mathrm{AA})$ versus $8.4 \pm 0.7 \mu \mathrm{mol} / \mathrm{kg} / \mathrm{min}(1.5 \pm 0.1 \mathrm{mg} / \mathrm{kg} / \mathrm{min})(\mathrm{g}+\mathrm{IL}$ $+\mathrm{AA})_{[\mathrm{U}-13 \mathrm{C}] \text { glucose }}(p=0.03)$ (Fig. 1). There were no significant differences in rates of total plasma appearance [29.8 \pm $1.3 \mu \mathrm{mol} / \mathrm{kg} / \mathrm{min}(5.4 \pm 0.2 \mathrm{mg} / \mathrm{kg} / \mathrm{min})(\mathrm{g}+\mathrm{AA})$ and $27.3 \pm$ $0.8 \mu \mathrm{mol} / \mathrm{kg} / \mathrm{min}(4.9 \pm 0.1 \mathrm{mg} / \mathrm{kg} / \mathrm{min})(\mathrm{g}+\mathrm{AA}+\mathrm{IL})_{[\mathrm{U}-}$

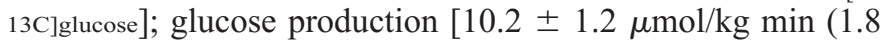
$\pm 0.2 \mathrm{mg} / \mathrm{kg} / \mathrm{min})(\mathrm{g}+\mathrm{AA})$ and $10.4 \pm 0.8 \mu \mathrm{mol} / \mathrm{kg} / \mathrm{min}(1.9$ $\pm 0.1 \mathrm{mg} / \mathrm{kg} / \mathrm{min})(\mathrm{g}+\mathrm{AA}+\mathrm{L})_{[\mathrm{U}-13 \mathrm{C}] \text { glucose }}$ (Fig. 2)]; or glycogenolysis $[3.9 \pm 1.5 \mu \mathrm{mol} / \mathrm{kg} / \mathrm{min}(0.7 \pm 0.3 \mathrm{mg} / \mathrm{kg} / \mathrm{min})$ (g + AA) versus $2.0 \pm 0.6 \mu \mathrm{mol} / \mathrm{kg} / \mathrm{min}(0.4 \pm 0.1 \mathrm{mg} / \mathrm{kg} /$ min) $(\mathrm{g}+\mathrm{AA}+\mathrm{IL})_{[\mathrm{U}-13 \mathrm{C}] \mathrm{glucose}}$ (Fig. 3)]. Excluding the data from the three infants receiving additional glucose did not change the results of the statistical analyses, i.e. when comparing the data from the remaining five infants of the $\mathrm{g}+\mathrm{AA}$ group with those of the $(\mathrm{g}+\mathrm{AA}+\mathrm{IL})_{[\mathrm{U}-13 \mathrm{C}] \text { glucose }}$ group, gluconeogenesis was significantly lower $[6.1 \pm 0.6 \mu \mathrm{mol} / \mathrm{kg} /$ $\min (1.1 \pm 0.1 \mathrm{mg} / \mathrm{kg} / \mathrm{min})](p=0.02)$, and rates of glucose production $[11.5 \pm 1.6 \mu \mathrm{mol} / \mathrm{kg} / \mathrm{min}(2.1 \pm 0.3 \mathrm{mg} / \mathrm{kg} / \mathrm{min})]$ and glycogenolysis $[5.4 \pm 2.0 \mu \mathrm{mol} / \mathrm{kg} / \mathrm{min}(1.0 \pm 0.4 \mathrm{mg} /$ $\mathrm{kg} / \mathrm{min}$ )] were not different.

\section{Withdrawal of parenteral amino acids (TrophAmine)}

None of the infants in the $\mathrm{g}+\mathrm{IL}$ group $(n=6)$ required any increase in the designed glucose infusion rate to maintain a glucose concentration $>2.2 \mathrm{mM}(40 \mathrm{mg} / \mathrm{dL})$. In fact, the glucose concentration was slightly higher in the $\mathrm{g}+\mathrm{IL}$ group $(4.6 \pm 0.6$ $\mathrm{mM})$ when compared with the previously studied $(\mathrm{g}+\mathrm{AA}+$
IL) ${ }_{[2-13 C] g l y c e r o l}$ group $(2.8 \pm 0.1 \mathrm{mM})(p=0.04)$. Plasma insulin concentrations were not affected by withdrawal of TrophAmine, $8.2 \pm 2.2 \mu \mathrm{U} / \mathrm{mL}(\mathrm{g}+\mathrm{IL})$ and $8.3 \pm 1.9 \mu \mathrm{U} / \mathrm{mL}(\mathrm{g}+\mathrm{AA}+$ IL) $[2-13 \mathrm{C}]$ glycerol Neither did differences in total plasma glucose appearance rates, $33.5 \pm 2.3 \mu \mathrm{mol} / \mathrm{kg} / \mathrm{min}(6.0 \pm 0.4 \mathrm{mg} / \mathrm{kg} / \mathrm{min})$ $(\mathrm{g}+\mathrm{IL})$ versus $29.3 \pm 1.9 \mu \mathrm{mol} / \mathrm{kg} / \mathrm{min}(5.2 \pm 0.3 \mathrm{mg} / \mathrm{kg} / \mathrm{min})$ $(\mathrm{g}+\mathrm{AA}+\mathrm{IL})_{[2-13 \mathrm{C}] \text { glycerol }}(p=0.2)$, nor those in glucose production rates reach significance, $16.8 \pm 2.3 \mu \mathrm{mol} / \mathrm{kg} / \mathrm{min}(3.0$ $\pm 0.4 \mathrm{mg} / \mathrm{kg} / \mathrm{min})(\mathrm{g}+\mathrm{IL})$ versus $11.3 \pm 1.8 \mu \mathrm{mol} / \mathrm{kg} / \mathrm{min}(2.0$ $\pm 0.3 \mathrm{mg} / \mathrm{kg} / \mathrm{min})(\mathrm{g}+\mathrm{AA}+\mathrm{IL})_{[2-13 \text { C]glycerol }}(p=0.09)($ Fig. 2). Total gluconeogenic rates were virtually identical in the $\mathrm{g}+\mathrm{IL}$ group, $7.5 \pm 0.8 \mu \mathrm{mol} / \mathrm{kg} / \mathrm{min}(1.4 \pm 0.1 \mathrm{mg} / \mathrm{kg} / \mathrm{min})$ and the $(\mathrm{g}$ $+\mathrm{AA}+\mathrm{IL})_{[2-13 \mathrm{C}] \mathrm{glycerol}}$ group, $7.9 \pm 0.9 \mu \mathrm{mol} / \mathrm{kg} / \mathrm{min}(1.4 \pm$ $0.2 \mathrm{mg} / \mathrm{kg} / \mathrm{min}$ ) (Fig. 1). The portions contributed by glycerol were also similar, $4.4 \pm 0.6 \mu \mathrm{mol} / \mathrm{kg} / \mathrm{min}(0.8 \pm 0.1 \mathrm{mg} / \mathrm{kg} / \mathrm{min})$ $(\mathrm{g}+\mathrm{IL})$ and $4.9 \pm 0.7 \mu \mathrm{mol} / \mathrm{kg} / \mathrm{min}(0.9 \pm 0.1 \mathrm{mg} / \mathrm{kg} / \mathrm{min})(\mathrm{g}+$ AA + IL $)_{[2-13 C] g l y c e r o l}$. Withdrawal of TrophAmine did, however, increase glycogenolysis, $9.3 \pm 1.8 \mu \mathrm{mol} / \mathrm{kg} / \mathrm{min}(1.7 \pm 0.3$ $\mathrm{mg} / \mathrm{kg} / \mathrm{min})(\mathrm{g}+\mathrm{IL})$ compared with $3.6 \pm 1.7 \mu \mathrm{mol} / \mathrm{kg} / \mathrm{min}(0.7$ $\pm 0.3 \mathrm{mg} / \mathrm{kg} / \mathrm{min})(\mathrm{g}+\mathrm{AA}+\mathrm{IL})_{[2-13 \text { C]glycerol }}(p=0.04)($ Fig. 3 ). Total glycerol turnover and endogenous glycerol turnover (an indicator of lipolysis) were virtually identical in the two groups, $15.0 \pm 1.7 \mu \mathrm{mol} / \mathrm{kg} / \mathrm{min}(1.4 \pm 0.2 \mathrm{mg} / \mathrm{kg} / \mathrm{min})(\mathrm{g}+\mathrm{IL})$ and $15.8 \pm 1.5 \mu \mathrm{mol} / \mathrm{kg} / \mathrm{min}(1.5 \pm 0.1 \mathrm{mg} / \mathrm{kg} / \mathrm{min})(\mathrm{g}+\mathrm{AA}+$ IL) $[2-13 \mathrm{C}] \mathrm{glycerol}$, and $7.2 \pm 1.1 \mu \mathrm{mol} / \mathrm{kg} / \mathrm{min}(0.7 \pm 0.1 \mathrm{mg} / \mathrm{kg} /$ $\mathrm{min})(\mathrm{g}+\mathrm{IL})$ versus $8.8 \pm 1.3 \mu \mathrm{mol} / \mathrm{kg} / \mathrm{min}(0.8 \pm 0.1 \mathrm{mg} / \mathrm{kg} /$ $\min )(\mathrm{g}+\mathrm{AA}+\mathrm{IL})_{[2-13 \mathrm{C}] \mathrm{glycerol}} \cdot$

\section{DISCUSSION}

The present study demonstrated that withdrawal of the lipid emulsion (Intralipid) from the TPN solution impaired gluconeogenesis, whereas excluding the amino acid solution (TrophAmine) did not at all affect gluconeogenesis in very premature

\section{Gluconeogenesis}

Withdrawal of Intralipid $\mathbb{R}$

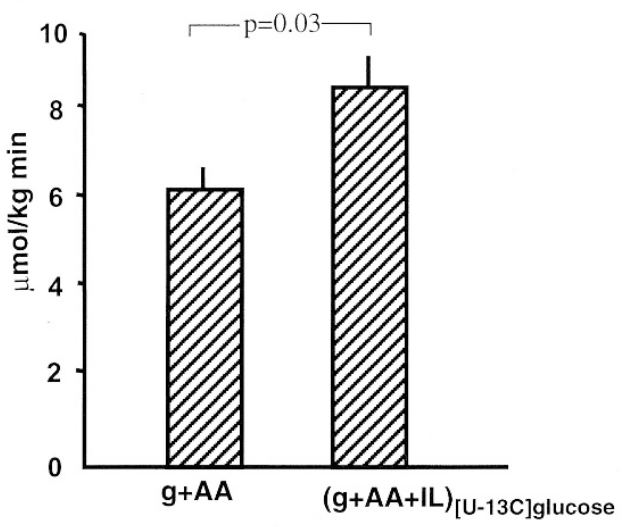

Withdrawal of TrophAmine ${ }^{\circledR}$

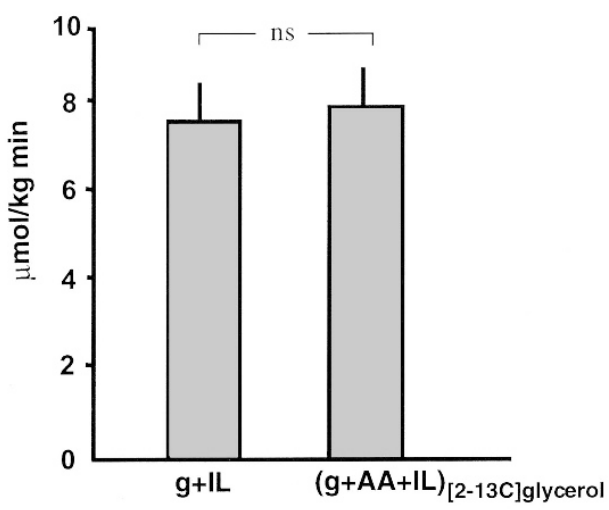

Mean \pm SE

Figure 1. Effects of withdrawal of Intralipid and TrophAmine, respectively, on rates of gluconeogenesis obtained between study hours 6-8; $\mathrm{g}+\mathrm{AA}$ : infants receiving glucose at $\sim 17 \mu \mathrm{mol} / \mathrm{kg} / \mathrm{min}(\sim 3 \mathrm{mg} / \mathrm{kg} / \mathrm{min})$ plus TrophAmine (studied by [U- $\left.{ }^{13} \mathrm{C}\right]$ glucose MIDA) $(n=8)$; $(\mathrm{g}+\mathrm{AA}+\mathrm{IL})_{[\mathrm{U}-13 \mathrm{C}] \text { glucose: }}$ previously studied infants receiving glucose at $\sim 17 \mu \mathrm{mol} / \mathrm{kg} / \mathrm{min}(\sim 3 \mathrm{mg} / \mathrm{kg} / \mathrm{min})$ plus TrophAmine plus Intralipid (studied by [U- $\left.{ }^{13} \mathrm{C}\right] \mathrm{glucose}$ MIDA) $(n=8) ; \mathrm{g}+\mathrm{IL}$ : infants receiving glucose at $\sim 17 \mu \mathrm{mol} / \mathrm{kg} / \mathrm{min}(\sim 3 \mathrm{mg} / \mathrm{kg} / \mathrm{min})$ plus Intralipid (studied by $\left[2-{ }^{13} \mathrm{C}\right]$ glycerol MIDA $(n=6) ;(\mathrm{g}+\mathrm{AA}+\mathrm{IL})_{[2-13 \mathrm{C}] \mathrm{glycerol}}$ : previously studied infants receiving glucose at $\sim 17 \mu \mathrm{mol} / \mathrm{kg} / \mathrm{min}(\sim 3 \mathrm{mg} / \mathrm{kg} / \mathrm{min})$ plus TrophAmine plus Intralipid (studied by $\left.\left[2-{ }^{13} \mathrm{C}\right] \mathrm{glycerol} \mathrm{MIDA}\right)(n=6)$. Cross-hatching designates infants studied by $\left[\mathrm{U}-{ }^{13} \mathrm{C}\right]$ glucose; shading designates infants studied by $\left[2-{ }^{13} \mathrm{C}\right] \mathrm{glycerol}$. 


\section{Glucose Production}

Withdrawal of Intralipid ${ }^{\circledR}$

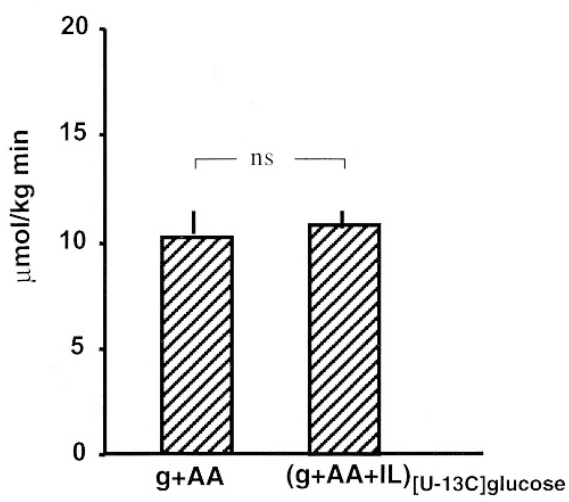

Withdrawal of TrophAmine ${ }^{\circledR}$

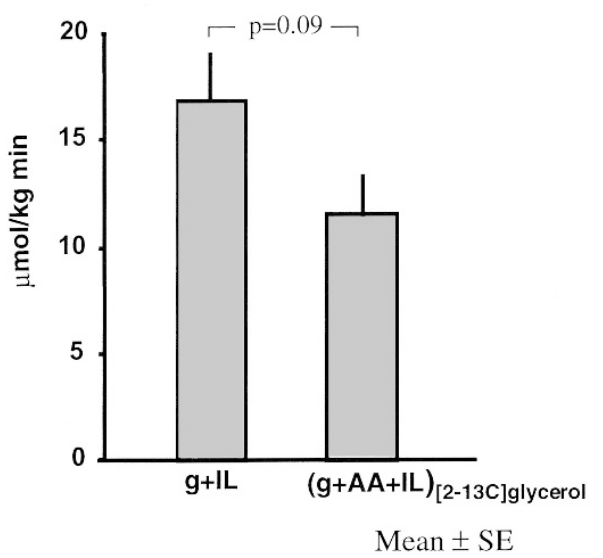

Figure 2. Effects of withdrawal of Intralipid and TrophAmine, respectively, on rates of glucose production obtained between study hours 6 and 8 ; g + AA: infants receiving glucose at $\sim 17 \mu \mathrm{mol} / \mathrm{kg} / \mathrm{min}(\sim 3 \mathrm{mg} / \mathrm{kg} / \mathrm{min})$ plus TrophAmine (studied by $\left[\mathrm{U}-{ }^{13} \mathrm{C}\right]$ glucose MIDA) $(n=8)$; $(\mathrm{g}+\mathrm{AA}+\mathrm{IL})_{[\mathrm{U}-13 \mathrm{C}] \mathrm{glucose}}$ : previously studied infants receiving glucose at $\sim 17 \mu \mathrm{mol} / \mathrm{kg} / \mathrm{min}(\sim 3 \mathrm{mg} / \mathrm{kg} / \mathrm{min})$ plus TrophAmine plus Intralipid (studied by [U- $\left.{ }^{13} \mathrm{C}\right] \mathrm{glucose}$ MIDA) $(n=8)$; $\mathrm{g}+\mathrm{IL}$ : infants receiving glucose at $\sim 17 \mu \mathrm{mol} / \mathrm{kg} / \mathrm{min}(\sim 3 \mathrm{mg} / \mathrm{kg} / \mathrm{min})$ plus Intralipid (studied by $\left[2-{ }^{13} \mathrm{C}\right]$ glycerol MIDA) $(n=6) ;(\mathrm{g}+\mathrm{AA}+\mathrm{IL})_{[2-13 \mathrm{C}] \mathrm{glycerol}}$ : previously studied infants receiving glucose at $\sim 17 \mu \mathrm{mol} / \mathrm{kg} / \mathrm{min}(\sim 3 \mathrm{mg} / \mathrm{kg} / \mathrm{min})$ plus TrophAmine plus Intralipid (studied by [2- $\left.{ }^{13} \mathrm{C}\right]$ glycerol MIDA) $(n=6)$. Cross-hatching designates infants studied by $\left[\mathrm{U}-{ }^{13} \mathrm{C}\right]$ glucose; shading designates infants studied by $\left[2-{ }^{13} \mathrm{C}\right] \mathrm{glycerol}$.

\section{Glycogenolysis}

Withdrawal of Intralipid $\mathbb{B}$

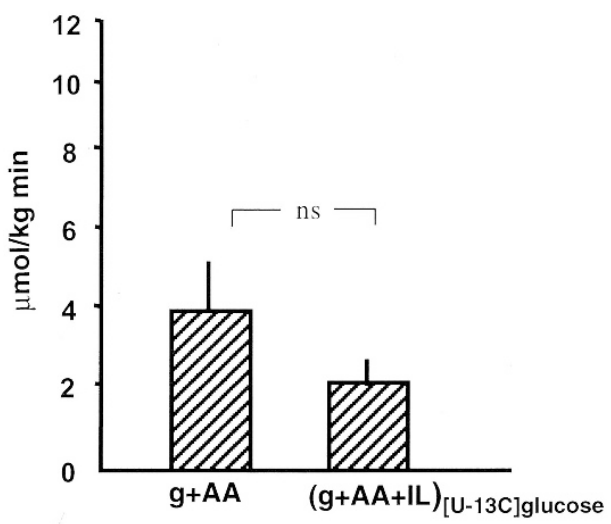

Withdrawal of TrophAmine ${ }^{\circledR}$

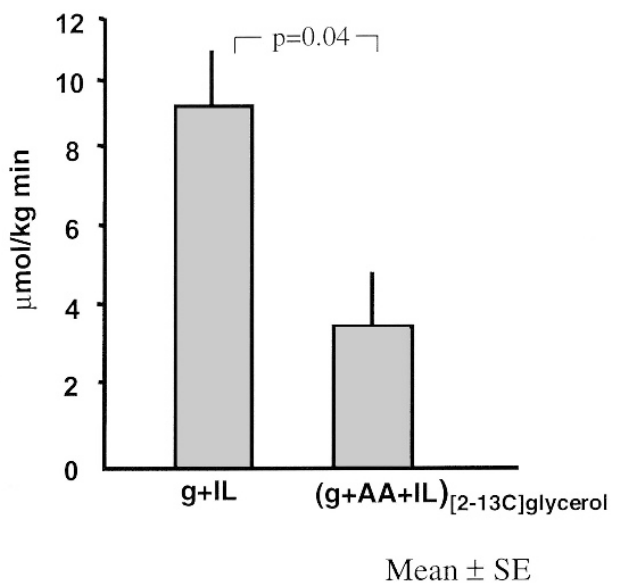

Figure 3. Effects of withdrawal of Intralipid and TrophAmine, respectively, on rates of glycogenolysis obtained between study hours 6 and 8 ; $g+$ AA: infants receiving glucose at $\sim 17 \mu \mathrm{mol} / \mathrm{kg} / \mathrm{min}(\sim 3 \mathrm{mg} / \mathrm{kg} / \mathrm{min})$ plus TrophAmine (studied by $\left[\mathrm{U}-{ }^{13} \mathrm{C}\right.$ ]glucose MIDA) $(n=8)$; $(\mathrm{g}+\mathrm{AA}+\mathrm{IL})_{[\mathrm{U}-13 \mathrm{C}] \mathrm{glucose}}$ : previously studied infants receiving glucose at $\sim 17 \mu \mathrm{mol} / \mathrm{kg} / \mathrm{min}(\sim 3 \mathrm{mg} / \mathrm{kg} / \mathrm{min})$ plus TrophAmine plus Intralipid (studied by [U- $\left.{ }^{13} \mathrm{C}\right] \mathrm{glucose}$ MIDA) $(n=8) ; \mathrm{g}+\mathrm{IL}$ : infants receiving glucose at $\sim 17 \mu \mathrm{mol} / \mathrm{kg} / \mathrm{min}(\sim 3 \mathrm{mg} / \mathrm{kg} / \mathrm{min})$ plus Intralipid (studied by [2- $\left.{ }^{13} \mathrm{C}\right]$ glycerol MIDA) $(n=6) ;(\mathrm{g}+\mathrm{AA}+\mathrm{IL})_{[2-13 \mathrm{C}] \mathrm{glycerol}}$ : previously studied infants receiving glucose at $\sim 17 \mu \mathrm{mol} / \mathrm{kg} / \mathrm{min}(\sim 3 \mathrm{mg} / \mathrm{kg} / \mathrm{min})$ plus TrophAmine plus Intralipid (studied by $\left.\left[2-{ }^{13} \mathrm{C}\right] \mathrm{glycerol} \mathrm{MIDA}\right)(n=6)$. Cross-hatching designates infants studied by $\left[\mathrm{U}-{ }^{13} \mathrm{C}\right]$ glucose; shading designates infants studied by $\left[2-{ }^{13} \mathrm{C}\right] \mathrm{glycerol}$.

infants receiving glucose at $\sim 17 \mu \mathrm{mol} / \mathrm{kg} / \mathrm{min}(\sim 3 \mathrm{mg} / \mathrm{kg} / \mathrm{min})$. In our previous study of very premature infants receiving an equal supply of glucose as part of TPN, normoglycemia was maintained by glucose produced primarily as a result of gluconeogenesis. Under these conditions, glycerol was the most important gluconeogenic substrate, contributing nearly half the total glucose produced by the infants (8). Collectively, the previous and present results would suggest that parenteral lipids are more important than the amino acids provided by TrophAmine in supporting gluconeogenesis.

The rates of gluconeogenesis and the gluconeogenic contribution from glycerol observed in infants receiving reduced glucose supply and Intralipid were virtually identical to those of the previously studied infants receiving both Intralipid and TrophAmine (8). Intralipid supported gluconeogenesis by providing gluconeogenic substrate in the form of both free and 
triglyceride-bound glycerol, but potentially Intralipid also provides FFA, which upon hepatic $\beta$-oxidation contributes energy to drive the gluconeogenic process (25). Although a number of amino acids are potential gluconeogenic substrates, the primary gluconeogenic amino acids are alanine and glutamine. Because TrophAmine contains only limited amounts of alanine and no glutamine (Table 2), the decrease in gluconeogenesis in infants receiving glucose at $\sim 17 \mu \mathrm{mol} / \mathrm{kg} / \mathrm{min}(\sim 3 \mathrm{mg} / \mathrm{kg} / \mathrm{min})$ and TrophAmine (but no Intralipid) could be anticipated. In addition, because these infants are growing at a high rate, exogenous amino acids may be directed into protein synthesis, resulting in smaller amounts being potentially available for gluconeogenesis.

Whereas withdrawal of Intralipid resulted in a significant decrease in rates of gluconeogenesis, withdrawal of TrophAmine did not at all affect gluconeogenesis. However, when TrophAmine was eliminated from the TPN solution, rates of glycogenolysis increased. Although the increased rates of glycogenolysis were somewhat surprising, their magnitude was quite plausible. The infants had received glucose at twice their basal glucose turnover rates plus appropriate amounts of lipids and amino acids for the 3-4 d preceding the study, thus, their glycogen stores were most likely maximally filled when the study commenced. Assuming a liver weight of $\sim 5 \%$ of the body weight $(47 \pm 12 \mathrm{~g}$ in a $1 \mathrm{~kg}$ infant) (2) and a glycogen content of $\sim 5 \%$ of the liver weight would result in a glycogen content of $\sim 2.4-2.5 \mathrm{~g}$. With a glycogenolytic rate of $9.3 \mu \mathrm{mol} / \mathrm{kg} / \mathrm{min}(1.7 \mathrm{mg} / \mathrm{kg} / \mathrm{min}=102 \mathrm{mg} / \mathrm{h})$ we could calculate that these stores would last for $\sim 23-25 \mathrm{~h}$ (2400/102-2500/102). From our current data, the mechanism responsible for the higher rates of glycogenolysis in the infants receiving only glucose and Intralipid cannot be determined. The observation that withdrawal of TrophAmine increases glycogenolysis suggests that the availability of amino acids in TrophAmine may actively inhibit glycogenolysis or may passively reduce it by secondary hormone or metabolite feedback effect. Because withdrawal of TrophAmine did not affect the insulin concentration [identical in the $\mathrm{g}+\mathrm{IL}$ and the $(\mathrm{g}+\mathrm{AA}+\mathrm{IL})_{[2-13 \mathrm{C}] \mathrm{glycerol}}$ groups], it is unlikely that this effect was mediated via insulin. It is well known that glucagon is a potent stimulator of glycogenolysis, although there are no data in humans demonstrating an acute effect of glucagons on gluconeogenesis. It is also known that some amino acids stimulate glucagon, although others may have the opposite effect (26). Thus, it is possible that TrophAmine inhibited glycogenolysis via inhibition of glucagon secretion. Limitations in the amount of plasma available from these infants precluded measurements of glucagon in this study.

Our data demonstrate that withdrawal of the lipid component of TPN (Intralipid ) impaired gluconeogenesis, suggesting that Intralipid plays a primary role in supporting gluconeogenesis. On a per gram basis, Intralipid is a very important source of energy, providing nearly three times that of glucose. Thus, providing glucose at a rate equivalent to the basal glucose turnover rate of these infants $(6-8 \mathrm{mg} / \mathrm{kg} / \mathrm{min}$ or $33-44 \mu \mathrm{mol} /$ $\mathrm{kg} / \mathrm{min})$ in addition to currently recommended rates of lipid $(\sim 3$ $\mathrm{g} / \mathrm{kg} / \mathrm{d}$ on d 3-4 of life) and amino acid substrate (important for protein synthesis) $(\sim 3 \mathrm{~g} / \mathrm{kg} / \mathrm{d})$ may be a potential strategy to reduce the risk of hyperglycemia without increasing the risk of either energy insufficiency $(27,28)$ or hypoglycemia.
Acknowledgments. The author thanks Drs. Dennis M. Bier and Morey W. Haymond at the Children's Nutrition Research Center, Houston, TX, for invaluable help and advice in designing this study, interpreting the results as well as in preparing this manuscript; Cindy Bryant, Pamela Burns, Ellen Newton, Pamela Gordon, and Cindy Clarke for excellent assistance; the pharmacist at Texas Children's Hospital for mixing TPN and preparing isotope solutions; and Dr. Richard Schanler and the staff of the neonatal intensive care unit for professional collaboration.

\section{REFERENCES}

1. Guyer B, Hoyert DL, Martin JA, Ventura SJ, MacDorman MF, Strobino DM 1999 Annual summary of vital statistics-1998. Pediatrics 104:1229-1246

2. Gruenwald P, Minh HN 1960 Evaluation of body and organ weights in perinatal pathology. I. Normal standards derived from autopsies. Am J Clin Path 34:247-253

3. Haymond MW, Sunehag AL 1999 Controlling the sugar bowl. Regulation of glucose homeostasis in children. Metab Endocrinol Clin North Am 28:663-694

4. Bier DM, Leake RD, Haymond MW, Arnold KJ, Gruenke LD, Sperling MA, Kipnis DM 1977 Measurement of "true" glucose production rates in infancy and childhood with 6,6 - dideuteroglucose. Diabetes 26:1016-1023

5. Dweck HS, Cassady G 1974 Glucose intolerance in infants of very low birth weight. I Incidence of hyperglycemia in infants of birth weights 1100 grams or less. Pediatrics 53:189-195

6. Wu S, Srinivasan G, Pildes RS 1990 Plasma glucose (G) values during the first month of life in infants $<1000$ gm. Pediatr Res 27:231A(abstr)

7. Lilien LD, Rosenfield RL, Baccaro MM, Pildes R 1979 Hyperglycemia in stressed small premature neonates. J Pediatr 94:454-459

8. Sunehag AL, Haymond MW, Schanler RJ, Reeds PJ, Bier DM 1999 Gluconeogenesis in very low birth weight infants receiving total parenteral nutrition. Diabetes 48:791-800

9. Lubchenco LO, Hansman C, Dessler M, Boyd E 1963 Intrauterine growth as estimated from live born birth-weight data at 24 to 42 weeks of gestation. Pediatrics 32:793-800

10. Ballard JL, Khoury JC, Wedig K, Wang L, Eilers-Walsman BL, Lipp R 1991 New Ballard score, expanded to include extremely premature infants. J Pediatr 119:417-423

11. Tayek JA, Katz J 1997 Glucose production, recycling, Cori cycle, and gluconeogenesis in humans: relation to serum cortisol. Am J Physiol 272:E476-E484

12. Hellerstein MK, Neese RA 1992 Mass isotopomer distribution analysis: a technique for measuring biosynthesis and turnover of polymers. Am J Physiol 263:E988-E1001

13. Neese RA, Schwartz J-M, Faix D, Turner S, Letscher A, Vu D, Hellerstein MK 1995 Gluconeogenesis and intrahepatic triose phosphate flux in response to fasting or substrate loads. J Biol Chem 270:14452-14466

14. Sunehag AL, Clarke L, Bier DM, Haymond MW 2001 [U- ${ }^{13}$ C]glucose MIDA provides accurate measures of gluconeogenesis, is easy to perform and requires only small blood sample volumes. Diabetes 50:A65

15. Landau BR, Wahren J, Chandramouli V, Schumann WC, Ekberg K, Kalhan SC 1996 Contributions of gluconeogenesis to glucose production in the fasted state. J Clin Invest 98:378-385

16. Peroni O, Large V, Beylot M 1995 Measuring gluconeogenesis with $\left[2-{ }^{13} \mathrm{C}\right]$ glycerol and mass isotopomer distribution analysis of glucose. Am J Physiol 269:E516-E523

17. Koh TH, Vong SK 1996 Definition of neonatal hypoglycemia: is there a change? J Pediatr Child Health 32:302-305

18. Cornblath M, Hawdon JM, Williams AF, Aynsley-Green A, Ward-Platt MP, Schwartz R, Kalhan SC 2000 Controversies regarding definitions of neonatal hypoglycemia: suggested operational thresholds. Pediatrics 105:1141-1145

19. Kalhan S, Peter-Wohl S 2000 Hypoglycemia: what is it for the neonate? Am J Perinatol 17:11-18

20. Bier DM, Arnold KJ, Sherman WR, Holland WH, Holmes WF, Kipnis DM 1977 In vivo measurement of glucose and alanine metabolism with stable isotope tracers. Diabetes 26:1005-1015

21. Bougnères PF 1987 Stable isotope tracers and the determination of fuel fluxes in newborn infants. Biol Neonate 2:87-96

22. Bougnères PF, Karl IE, Hillman LS, Bier DM 1982 Lipid transport in the human newborn. Palmitate and glycerol turnover and the contribution of glycerol to neonatal hepatic glucose output. J Clin Invest 70:262-270

23. Patel D, Kalhan S 1992 Glycerol metabolism and triglyceride-fatty acid cycling in the newborn: effects of maternal diabetes and intrauterine growth retardation. Pediatr Res $31: 52-58$

24. Sunehag A, Ewald U, Gustafsson J 1996 Extremely preterm infants ( $<28$ weeks) are capable of gluconeogenesis from glycerol on their first day of life. Pediatr Res 36:550-557

25. Chu CA, Sherk SM, Igawa K, Sindelar DK, Neal DW, Emshwiller M, Cherrington AD 2002 Effects of free fatty acids on hepatic glycogenolysis and gluconeogenesis in conscious dogs. Am J Physiol Endocrinol Metab 282:E402-E411

26. Rocha DM, Faloona GR, Unger RH 1972 Glucagon-stimulating activity of 20 amino acids in dogs. J Clin Invest 51:2346-2351

27. Sauer PJ, Carnielli VP, Sulkers EJ, van Goudoever JB 1994 Substrate utilization during the first week of life. Acta Paediatr Suppl 405:49-53

28. Micheli JL, Pfister R, Junod S, Laubscher B, Tolsa JF, Schutz Y, Calame A 1994 Water, energy and early postnatal growth in preterm infants. Acta Paediatr Suppl 405:35-42 